\title{
Does the national innovation system spur economic growth in Brazil, Russia, India, China and South Africa economies? Evidence from panel data
}

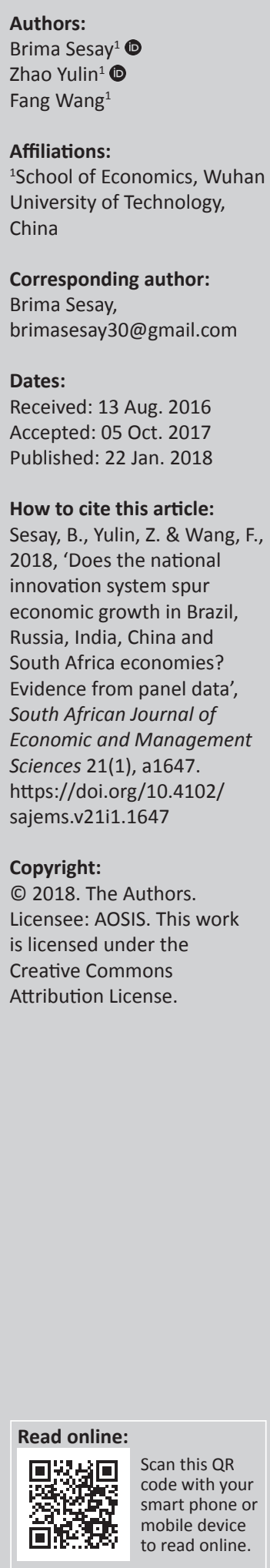

The question as to whether the national innovation system (NIS) plays a significant positive role in influencing economic growth has been intensely debated by academics as well as policy analysts. The main controversy, however, is the fact that the ongoing empirical evidences on the relationship between innovation and economic growth are still mixed. The aim of this paper is to provide further evidence on the relationship between the NIS and economic growth using consistent and reliable data from a sample of emerging economies (Brazil, Russia, India, China and South Africa [BRICS]). The research has a BRICS focus and constructs NIS using historical panel data set for the main variables, that is, university enrolment rate for science and engineering students, government research and development expenditure, high-tech export and the enclosure of control variables covering the period 2000Q1-2013Q4. The study employed a dynamic panel estimation technique with a view of evaluating the relative impact of the NIS on economic growth in BRICS. The results revealed that the NIS as a whole has a positive effect on economic growth in BRICS economies. An important policy implication emerging from this study is that extra efforts are needed by emerging economies to promote the development of a NIS so as to explore the potential growth-inducing effects of a well-functioning NIS. Consequently, findings from this study have offered some persuading indicators for BRICS economies to explore the development of a NIS as a potential opportunity to speed up their economic growth.

\section{Introduction}

Contemporary suppositions of economic growth draw attention to endogenous technological change to explain the growth pattern of world economies. According to the endogenous growth models, established by Romer $(1986 ; 1990)$, technological innovation which is known today as technovation is generated in the research and development (R\&D) sectors using human capital and the existing stock of knowledge. It is then utilised in the production of finished goods and results in constant increase in the output growth rate. At the centre of these models, it is their notion that innovation that can be determined endogenously will enable sustainable economic growth, if there are constant returns to innovation with respect to human capital used in the R\&D sectors.

In general, empirical works of endogenous growth models entail examining the outcome of R\&D variables on total factor productivity (TFP) growth. For example, in evaluating the soundness of growth models based on R\&D, Jones (1995) employs the plots of TFP growth and the rate of growth of the number of engineers and scientists in Japan, Germany, France and the United States using time series. However, in his study, there is no evidence of positive correlation between these variables. Aghion and Howitt (1998) give clarifications for the contradicting results of Jones (1995). First and foremost, the growing complexity of technology makes it essential to increase R\&D over time just to maintain the rate of innovation constant for every product. Secondly, innovation in each product tends to affect a smaller proportion of the economy as a whole when there is an increase in the number of products and, thus, has a lesser relative spillover effect on the total knowledge stock. They subsequently contend that gross domestic product (GDP) share of R\&D investment is supposed to be employed to account for the size of the economy instead of the number of the engineers and scientists. Scherer (1982), Griliches and Lichtenberg (1984), Aghion and Howitt (1998) and Zachariadis (2003) offer solid evidence that TFP growth and R\&D investment are positively related in the US economy. 
However, innovation in emerging economies in recent years has been exceptional and has contributed to the overall economic growth of countries. A good number of empirical studies had shown that there is a positive relationship between innovation and economic growth, and innovation has now become a major component of growth of economies across the globe. This article investigates the impact of national innovation system (NIS) on the economic growth of Brazil, Russia, India, China and South Africa (BRICS) between 2000 and 2013.

Nevertheless, understanding about BRICS's innovation potential and capacity is very crucial for a better understanding of the existing concept. Has the NIS played a role in the economic growth of BRICS in the past decade? What are the major components of BRICS's NIS? How can the NIS be enhanced? These are some of the questions that are to be explored in this study. A comprehensive understanding of these questions is essential for policymaking and hence the transformation of the economic growth model of BRICS towards a sustainable pattern. In the existing literature, there are many studies that investigated the contribution of TFP changes to economic growth (see Frantzen 2000; Griffith, Redding \& Van Reenen 2002). Innovation in those studies is considered as part of the role played by TFP or the leftover of economic growth which is not explicated by changes in factor inputs as it is clearly understood that markets relying on only input resources and price signals will not always be as effective in spurring higher productivity and hence economic growth. This study expands the existing literature by focusing on the major components of national innovation with an enclosure of control variables and by evaluating innovation from a different approach. The latter is based on BRICS official data and perhaps endeavoured for the first time in this article. The rest of the paper commences with a brief review of literature and the main issues associated with innovation in BRICS. This is followed by the description of the analytical framework and empirical model specification. The estimation results and discussions are then presented. Subsequently, relative analysis is accomplished in order to check the robustness of the main models. The article finally ends with a summary of the main findings and some concluding remarks.

\section{Literature review}

The concept of national innovation system was first proposed by Freeman as a response to the Washington consensus and to the neoclassical approaches to growth. In this way, the concept of the NIS has always been inherently linked to public policy. For Freeman and others, technological change and innovation are central to economic growth - a notion Freeman pointed out as obvious since the industrial revolution had already been well established by Schumpeter (1969). However, in view of this, innovation is not only perceived as the work of individual business entities but also as a collective effort that needs a different set of knowledge resources and know-how. As such, different countries will have different capabilities for innovation. Unlike the neoclassical view of growth, the NIS concepts put forward that governments and supportive agencies can play an essential coordinating role in the creation as well as the diffusion of innovation in a national economy. Freeman (1982) made this point quite understandable in his analysis of Japan's post-war 'catching up' policy. In other words, institutions matter. They can create and support an environment through which collective knowledge and resources can be more easily exchanged for the pursuit of new ideas and opportunities.

While the NIS concept took hold as a policy prescription for catching up and was further strengthened by the popularity of Porter's (1990) theory of the 'comparative advantage of nations', early concept of the NIS came under increasing criticism for being too blurred, open to misunderstanding and extremely broad to the point of losing practicality, as well as hesitations that the national prominence of the concept missed what was felt to be the more important underlying processes through which innovation actually came about. As a result, several concepts were developed that, while grounded in innovation systems, theory and ideas of collective learning and path dependency, considered innovation 'at other stratum of the economy than the nation state'. As was initially mentioned, the first approach was the technology systems approach that was put forward by Carlsson and Stankiewicz (1995) which commences with a specific technology and looks at what players and institutions affect its development and diffusion. The second was the sectoral systems of innovation approach developed by Breschi and Malerba (1997) who argued that innovation could be best understood by looking at a set of products and a diverse set of representatives who work together through a system in the creation, production and sale of those products. These representatives cleave to sectorspecific knowledge and their connections are influenced by institutions that may have local and international elements. Notably, Breschi and Malerba contend that looking at innovation at the sector level presents better understanding on how sectors and hence sets of technologies interplay and change with time.

The third approach was the regional innovation systems (RIS) concept which proposes that innovation is best understood as a local or regional phenomenon where interplay, exchange of knowledge and learning take place by connecting actors and institutions that are location bound. The concept of RIS hinges on the surveillance that technologically advanced (high-tech) inventive activities seem to hold in a selected number of modern regions of high capacity - made up of government organisations, legal and financial institutions, research universities and skilled labour - and that the tacit and asymmetric knowledge flows that characterise innovation are best channelled via face-toface communication which co-location makes easy. 
Exploring beyond the main structural framework presented by the NIS concept, approaches to innovation systems such as those mentioned above looked to not only how innovation systems enhance the emergence and diffusion of innovation but also the degree to which such systems are successful in doing so. To this end, Jacobsson and Johnson (2000) proposed a functions approach to innovation systems which set out to first identify the primary functions of an effective innovation system and to then determine the relative importance of various functions and related interactions pertaining to both the innovation process and the growing capacity of a particular innovation system. What was somewhat novel about this approach is that while it was applied primarily to technology innovation systems (i.e. the micro system level), the set of functions ultimately recognised can indisputably be used for comprehending the innovation systems at diverse stages of analysis, starting from technological and subdivision system levels right through to the regional systems levels and national systems levels.

\section{Empirical studies}

A vast amount of study has focused on the factors that influence growth via innovation in emerging economies. Most of these studies use $R \& D$ and patent as a measure of innovation in determining the influence of innovation on growth. Gould and Gruben (1996) investigated economic growth rates across many countries to a simple index of patent strength and other variables. They found a significant positive impact when patent was interacted with a measure of openness to trade. That is, growth increases by $0.66 \%$ on average because of the impact of stronger patents in open economies, suggesting that market liberalisation in concert with stronger intellectual property rights (IPRs) increases growth. Ginarte and Park (1997) arrived at a similar finding in investigating the influence of IPRs on growth and investment. They found a strong correlation of patents on substantial savings and R\&D expenses, which in turn enhance growth performance. Hall and Ziedonis (2001) had focused on patents in the US semiconductor industry. They explored the strengthening of patent policies of the 1980s using quantitative analysis of firm-level data on R\&D and patenting and industry interviews. They found that largescale manufacturers appear to be engaged in 'patent portfolio races'. Falvey, Foster and Greenaway (2006) used panel data for 80 countries in investigating the impact of IPRs on economic growth. Findings of their study showed that IPRs are significant and positively correlated for lowincome and high-income countries but not for middleincome ones.

McCalman (2005) tested the endogenous model for 27 most developed countries. Findings of the study showed that in the short run the majority of the countries' losses are because of a distribution of wealth to foreign owners of technology. However, in the long run, when the
TRIPS $^{1}$ provided incentives to research efforts, all countries benefited. Smith (2001) examined the simultaneous impact of IPR protection on US exports, affiliated sales and licenses to unaffiliated foreign firms in a sample of 50 developed and developing countries using a variant of the gravity equation. Results suggested that strong IPR protection increases the benefits of locating abroad and leads to an increase in affiliate sales and licensing relative to exports, particularly in countries with strong initiative abilities.

Patricia Hiqino Schneider (2005) investigated the role of high technology, IPRs and Foreign Direct Investment in determining a country's rate of innovation and economic growth by employing a distinctive panel data set of 47 developing countries from 1970 to 1990. The results are broadly consistent and suggested that (1) high-tech imports are necessary in explaining domestic innovation both in developing and developed countries; (2) the per capita GDP growth has a stronger impact on foreign technology; (3) IPRs have a significant impact in developed countries in terms of innovation. However, FDI results were inconclusive. Dutta and Sharmat (2008) investigated the effect of IPRs on innovation using panel data on Indian firms between 1989 and 2005. Results suggested that Indian firms increased their $R \& D$ expenditure after TRIPS in more innovation-intensive industries. The R\&D spending after TRIPS was an average of 20 percentage points higher in an industry with a one standard deviation higher value of innovation intensity.

Intarakumnerd, Chairatana and Tangchitpiboon (2002) investigated the concept of the NIS in developing countries that are said to be less successful in catching up with regard to technology. The study used Thailand as a case study and found that the development level of the NIS in Thailand has no link to the structural development level of its economy. They found that although Thailand experienced structural changes from agriculture-dominated economy to an industrial predominantly oriented one, its NIS remains feeble and fragmented. Yanrui Wu (2012) used regional data in examining the impact of innovation on economic growth in China. His findings revealed that innovation affects China's economic growth positively and R\&D positively impacts China's regional innovation. In the same line, Hulya Ulku (2007) assessed the relationship between $R \& D$, innovation and economic growth with a panel of 20 OECD and 10 non-OECD countries. He found a positive relationship between GDP per capita and innovation in both OECD and non-OECD countries even though the effect of R\&D stock on innovation was significant in only the OECD countries with large markets.

\section{Literature gaps}

Enormous empirical literature has been developed to examine the relationship between innovation and growth as

1.TRIPs is an agreement formulated in 1994 in an attempt to bridge the gaps in the way and manner IPR are protected around the globe. For more detailed analysis, see Dutta and Sharmat (2008:2) 
a whole; however, the outcomes on empirical substantiation are different depending on the selection of country, time frames and the applied methodology. This study's objective is therefore to complement the existing literature in two ways:

- To the knowledge of the authors, there is a need of logical study on identifying the major components in a NIS that influence economic growth in BRICS vis-à-vis that of other emerging economies.

- There is limited research that disaggregates the major components of the NIS and accounts for control variables in determining economic growth in emerging countries.

This study therefore aims to examine in a more holistic framework the role of the NIS, with a disaggregation of its major components and the enclosure of control variables as potential contributors to economic growth in emerging economies.

\section{Innovation and economic growth in Brazil, Russia, India, China and South Africa}

Innovation capacity explains much of the GDP growth in BRICS in the past decade, especially in China and India. Their development of the NIS via heavy investment of R\&D expenditure and personnel, patents and high-tech and service exports reinforce the capacity of their innovativeness. Through connecting the science sector with the business sector, providing incentives for innovative activities and complementing the import of technology and indigenous $R \& D$ effort, these countries experienced rapid economic growth in recent years. The degree to which these five countries have reallocated to the national system approach of innovation may to some extent be reflected in the trends of their research allocations, as reflected in the rate of expenditure on R\&D to their GDP. This may present a mere signal of a move towards a firm national base for the control of the means of innovation. The trends of R\&D expenditure ( $\%$ of GDP) of BRICS are presented in Table 1 as well as in Figure 1.

The BRICS member country that shows the strongest upward trend is China followed by Brazil. The indicator for India remains relatively constant over the 14 years for which data were collected, while the one for Russian Federation shows a fluctuating performance. In the case of South Africa, we see a slight deterioration over the last 2 years, caused by a drop in $\mathrm{R} \& \mathrm{D}$ expenditure. Although this measure may be too comprehensive to provide anything more than a basic indicator of the shifting knowledge base of the various economies, it is interesting to note that the measure for most of the BRICS countries still lies considerably within this method. The rates of growth of this indicator for China and Brazil over the 14-year period are impressive, especially in the case of China which shows a continuous upward trend.

Development of innovative activities has become a focal point of two major organisations: World Intellectual Property Organization and the International Business School INSEAD, which measure innovative development via a global innovation index. Another indicator of the closely defined NIS for the BRICS is provided in Figure 2 which illustrates high technology exports (high R\&D intensity) as a percentage of manufacturing exports that shows similar patterns with

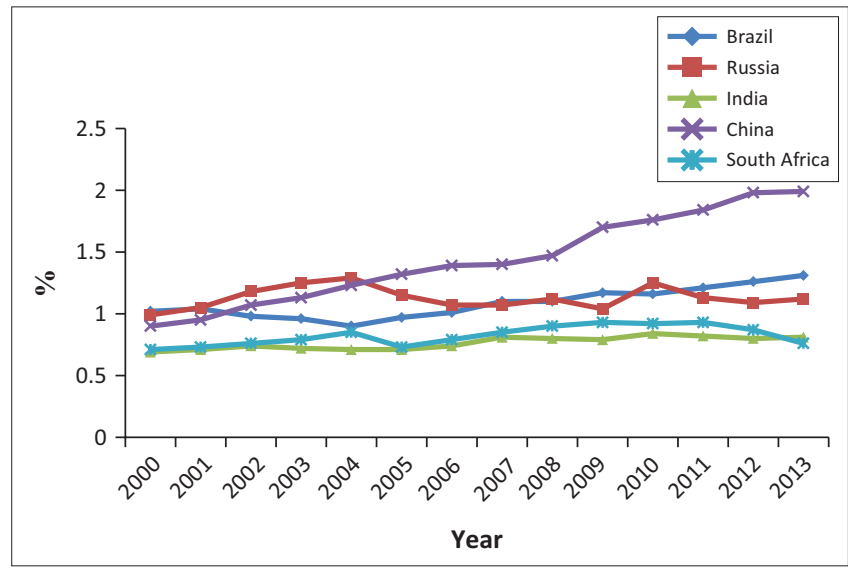

FIGURE 1: Research and development expenditure (\% of gross domestic product)

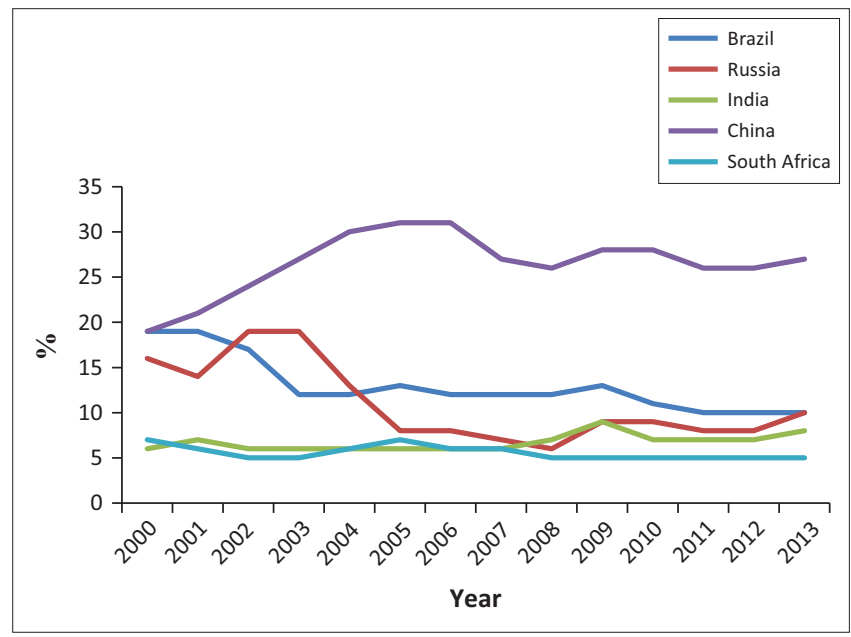

FIGURE 2: High-tech exports as a percentage of manufacturing exports.

TABLE 1: Research and development expenditure (\% of gross domestic product).

\begin{tabular}{lllllllllllllll}
\hline Country & $\mathbf{2 0 0 0}$ & $\mathbf{2 0 0 1}$ & $\mathbf{2 0 0 2}$ & $\mathbf{2 0 0 3}$ & $\mathbf{2 0 0 4}$ & $\mathbf{2 0 0 5}$ & $\mathbf{2 0 0 6}$ & $\mathbf{2 0 0 7}$ & $\mathbf{2 0 0 8}$ & $\mathbf{2 0 0 9}$ & $\mathbf{2 0 1 0}$ & $\mathbf{2 0 1 1}$ & $\mathbf{2 0 1 2}$ & $\mathbf{2 0 1 3}$ \\
\hline Brazil & 1.02 & 1.04 & 0.98 & 0.96 & 0.90 & 0.96 & 0.90 & 0.97 & 1.01 & 1.10 & 1.11 & 1.17 & 1.16 & 1.21 \\
Russia & 0.99 & 1.05 & 1.18 & 1.25 & 1.29 & 1.15 & 1.07 & 1.07 & 1.12 & 1.04 & 1.25 & 1.13 & 1.09 & 1.12 \\
India & 0.69 & 0.71 & 0.74 & 0.72 & 0.74 & 0.71 & 0.74 & 0.81 & 0.80 & 0.79 & 0.84 & 0.82 & 0.80 & 0.81 \\
China & 0.9 & 0.95 & 1.07 & 1.13 & 1.13 & 1.23 & 1.32 & 1.39 & 1.40 & 1.47 & 1.70 & 1.76 & 1.84 & 1.98 \\
$\begin{array}{l}\text { South } \\
\text { Africa }\end{array}$ & 0.71 & 0.73 & 0.76 & 0.79 & 0.85 & 0.73 & 0.79 & 0.85 & 0.90 & 0.93 & 0.92 & 0.93 & 0.87 & 0.76 \\
\hline
\end{tabular}

Source: The World Bank, 2014, World Development Indicators, International Bank for Reconstruction and Development/The World Bank, Washington DC 
slight variations for Brazil, Russia, India and South Africa though China has the highest performance for BRICS member countries.

Figure 2 clearly gives an idea about the upward movement of the Chinese NIS, not only with respect to size or its exportled growth but also in the high knowledge intensity of its export base.

Additional science and technology indicators which may be used as rough substitutes for intensifying the technological base of the different NISs in the BRICS countries are accounted for in the model and their graphical representations are shown in the appendices. Patent data have increased consistently in all of the BRICS countries over the period 2000-2013 (except for South Africa), with China demonstrating the highest growth rate (Appendix 1). Patent grant data (Figure 3) show that in the case of Russia by far the greater portion of patents that were granted had been consistently filed by residents throughout the 14-year period. This is perhaps owing to the historical improvement of a very strong research base and the training of engineers and scientists (scientific personnel) prior to the formation of the Russian Federation. The Chinese scenario, the only other BRICS member country where patent grants to residents surpasses those granted to foreigners, is different altogether. It is not just the complete scale of patents which is remarkable by the BRICS standards. The data also show an exponential rise in patents over the period with a reversal of the resident/non-resident ratio of patents granted from 2009 and a skyrocketing increase in the proportion of indigenes in the approved patents statistics. Figures 3-7 show patent grants by source for the BRICS economies.

Another significant element contributing to the development of an overall innovative environment is the economic freedom of a country. It should be noted that the notion of economic freedom has been intensely debated to be an important factor encouraging innovative activities by nations across the globe (Valetina, Sergey \& Sergey 2013). It is therefore imperative that transferring responsibilities and some of the economic functions of the state to the private sector as a rule will lead to a significant increase in social

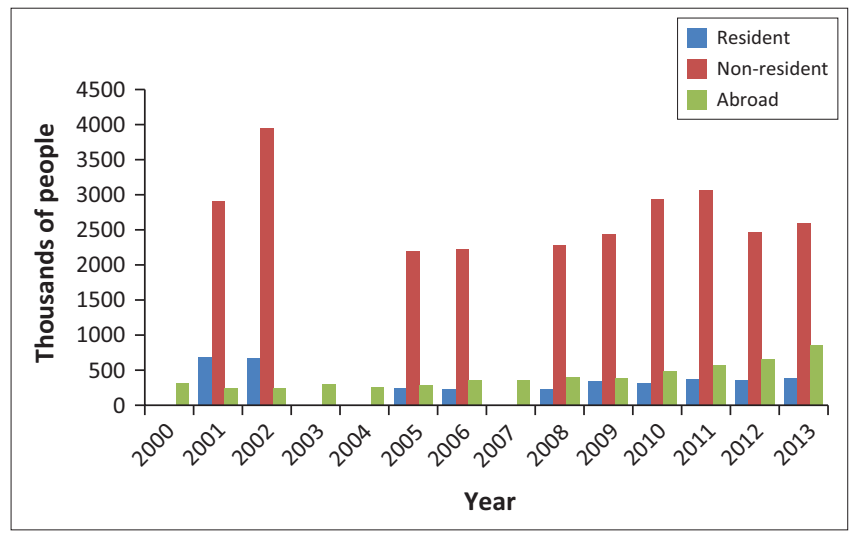

Source: Computed by authors from WIPO statistical service http://www.wipo.int/ipstats/en/ statistics/country_profile/

FIGURE 3: Patent grants by source for Brazil. welfare. Thus, governments sustaining a policy of economic freedom create an enabling environment for innovation which eventually leads to growth. According to the world ranking of economic freedom in 2013, South Africa was

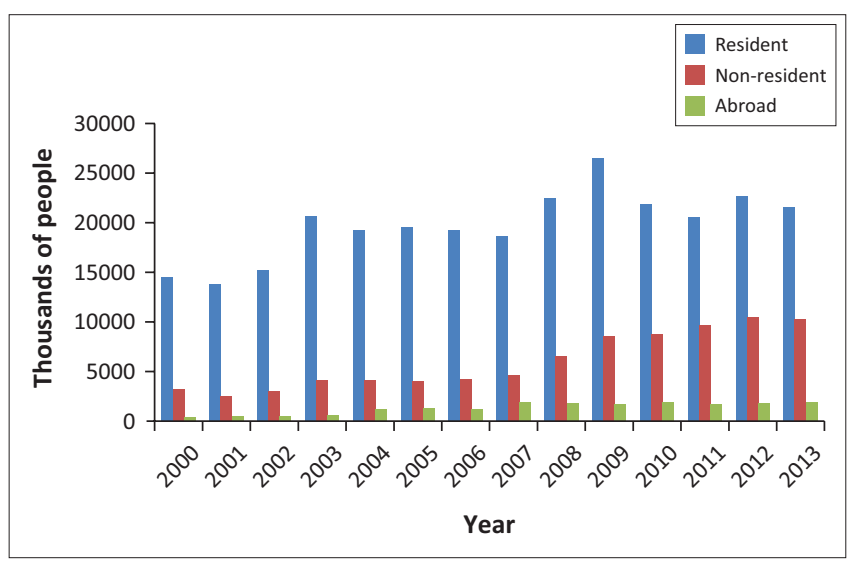

Source: Computed by authors from WIPO statistical service http://www.wipo.int/ipstats/en/ statistics/country_profile/

FIGURE 4: Patent grants by source for Russia (thousands of people).

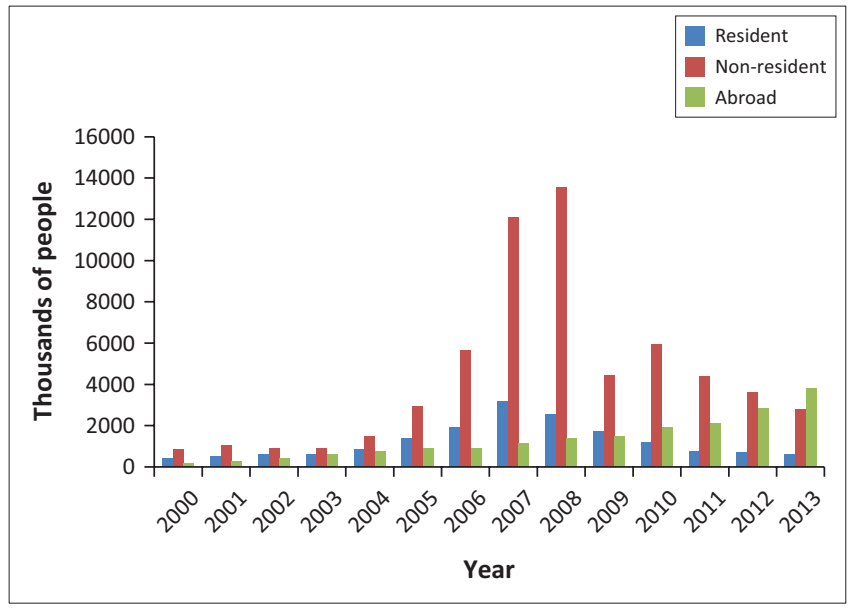

Source: Computed by authors from WIPO statistical service http://www.wipo.int/ipstats/en/ statistics/country_profile/

FIGURE 5: Patent grants by source for India (thousands of people).

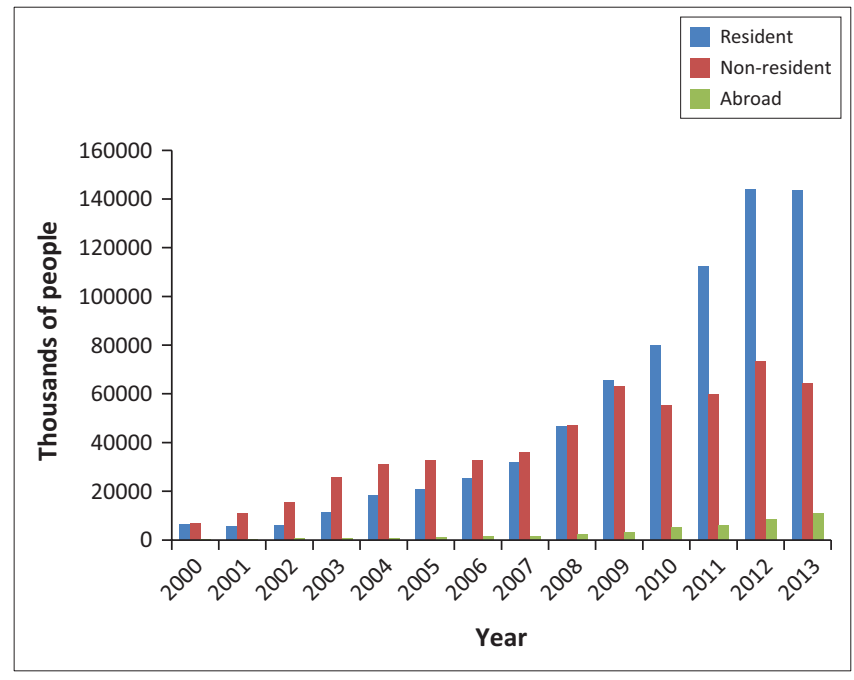

Source: Computed by authors from WIPO statistical service http://www.wipo.int/ipstats/en/ statistics/country_profile/

FIGURE 6: Patent grants by source for China (thousands of people). 


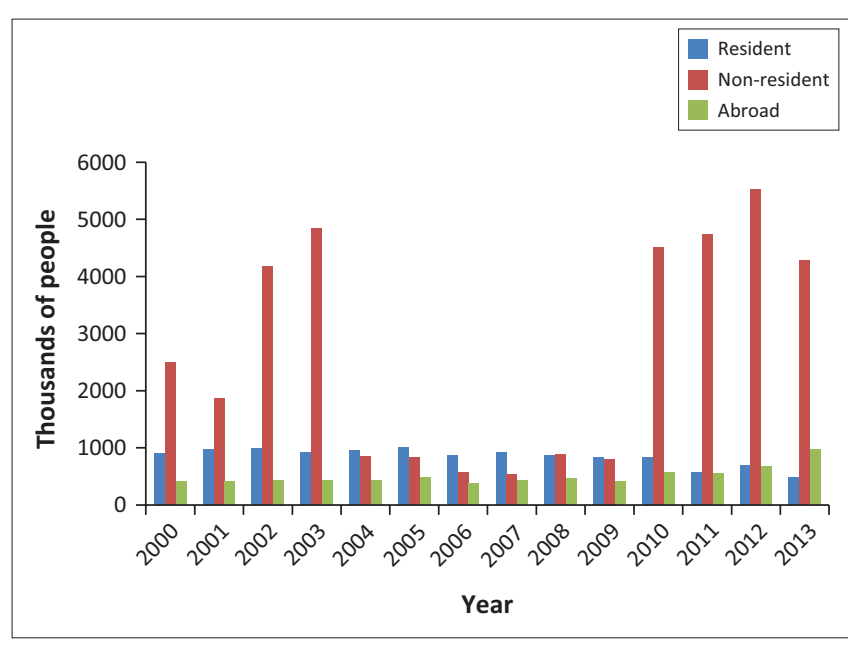

Source: Computed by authors from WIPO statistical service http://www.wipo.int/ipstats/en/ statistics/country_profile/

FIGURE 7: Patent grants by source for South Africa (thousands of people).

ranked 74th in the overall list of 176 countries, whereas Brazil, India, China and Russia were ranked 96th, 123rd, 136th and 140th, respectively. However, all the BRICS members were below the average score ${ }^{2}$ except South Africa (The Global Economy 2013).

Nevertheless, the indicators explained above refer to the narrow science and technology description of the NIS and can be ambiguous as indications of the capacity of the broader NIS to adjust to the post-industrial approach of innovation. The inconsistencies inherent in the broad capitalist approach of innovation, especially between growth and human development, are inevitable throughout the BRICS economies. This study had tried to bridge this gap by accounting for control variables in explaining the impact of the NIS on growth.

Based on the literature reviewed, the NIS basically consists of three segments: universities, governments and the businesses, with each segment interacting with the others, while at the same time playing their individual roles. Figure 8 is a simple illustration of how these three key players come to form the NIS. It is also important to note that the NIS is a complex conglomerate of interacting independent parties that has to do with the ability to plan and integrate policies and institutions.

The universities play the role of undertaking basic science and technology research, and educate scientists and technologists needed by governments and business. Governments in turn play the role of designing IPR systems for universities and businesses, commissioning science research, for example for defence purpose, subsidising business R\&D and financing universities. Businesses then play the role of conducting R\&D to develop commercial products, launch innovative products and start up new firms to exploit new science. The study, therefore, estimates a set of

2.The average economic freedom overall index for 2013 was 59.78 index points. The overall index of economic freedom has 10 elements clustered into four broad categories: rule of law, limited government, regulatory efficiency and open markets. http://www.theglobaleconomy.com/rankings/economic_freedom/

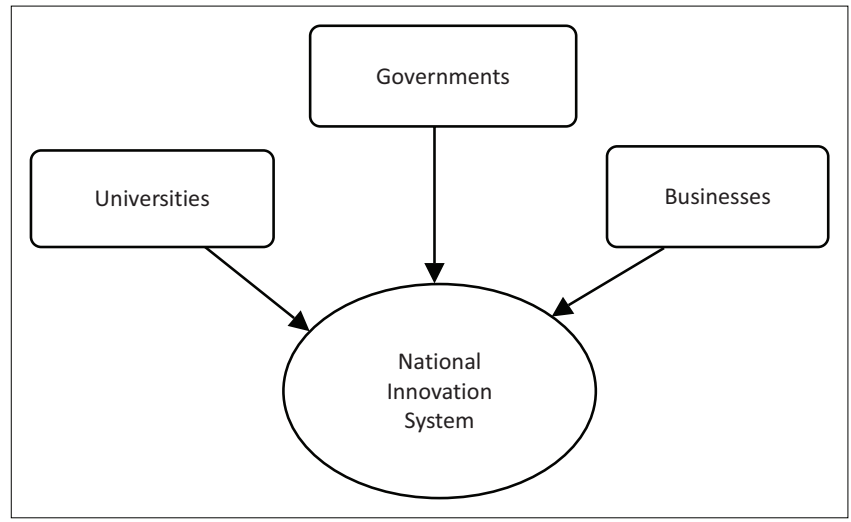

FIGURE 8: Disaggregated components of the national innovation system.

major components of the NIS which form an integral part of the three key players (business, university and government) with an enclosure of control variables that have potential in influencing economic growth.

\section{Data and empirical model specification}

\section{Data source}

The study envisages the collection of consistent and reliable panel data spanning from 2000 to 2013 for the selected emerging economies, namely Brazil, Russian Federation, India, China and South Africa. The essential data set for the selected countries was sourced from the International Financial Statistics, World Intellectual Property Organization statistics database and the World Bank database 2014. The selection of the variables was however limited to data availability and the common characteristics of the economies involved in the present study. The panel data set was transformed to quarterly data from 2000Q1 to 2013Q4, owing to the availability of data so as to increase the sample size. The quarterly data were obtained through interpolation of the annual time series data using E-views version 7.2. This was done using the low frequency to high frequency method and the quadratic match average and quadratic match sum for each observation of the low frequency series.

\section{Empirical model specification and estimation techniques}

Following an endogenous growth framework, the study specifies a model that best captures the effect of NIS on economic growth. Given the growing empirical evidence supporting the positive effect of innovation on economic growth (Ulku 2007; Wu 2012), we control for other factors that influence long run growth and generalise the specification of a growth equation that accounts for the effects of the NIS on economic growth. Thus, in deriving our empirical model for estimating this relationship for BRICS, we posit that:

$\ln \left(Y_{i t}\right)=\alpha+\beta_{1} \ln \left(U E_{i t}\right)+\beta_{2} \ln \left(R D_{i t}\right)+\beta_{3} \ln \left(T M_{i t}\right)+\lambda_{1} \ln \left(P T_{i t}\right)+$ $\lambda_{2} \ln (S P i t)+\lambda_{3} \ln \left(S J A_{i t}\right)+\lambda_{4} \ln \left(E F_{i t}\right)+\eta_{i}+\varepsilon_{i t} \quad$ [Eqn 1] 
The independent variables are defined as follows:

- $\mathrm{UE}=$ university enrolment rate for science and engineering students as a proxy for university

- $\mathrm{RD}=$ government research and development expenditure as a proxy for government

- $\mathrm{TM}=$ value of high-tech export as a proxy for business

- $\mathrm{PT}=$ total number of patents

- $\mathrm{SP}=$ scientific personnel

- $\mathrm{SJA}=$ scientific and technical journal articles

- $\mathrm{EF}=$ economic freedom

- $\varepsilon=$ error term

- $\beta_{\mathrm{i}}=$ measures the relative effect of the NIS on growth

- $\lambda_{\mathrm{i}}=$ set of parameters measuring the relative effect of the control variables.

Equation 1 is the basis of estimating the relationship between economic growth and our measure of the NIS. The application of the pooled OLS estimation will be appropriate if the unobserved country-specific effects, $\boldsymbol{\eta}_{\boldsymbol{i}}$ are uncorrelated with the independent variables. In contrast, the pooled OLS estimation will be unbiased and inefficient in a situation where a strong correlation exists between the unobserved individual effects, $\boldsymbol{\eta}_{i}$ and the independent variables. In such a scenario, the fixed effect model will be more appropriate in estimating the parameters of the model. In a situation where the assumptions of the standard random effect holds given that the model does not in fact contain unobserved effects, the pooled OLS will not only be efficient but the associated statistics will also be asymptotically valid. The study employs an $\mathrm{AR}(2)$ test for serial correlation in verifying for the absence of unobserved effect. This test's appropriateness is built on the assertion that the idiosyncratic errors are serially uncorrelated under the null $\mathrm{H} 0: \delta_{\eta}^{2}=0$, when the independent variables are exogenous. Using this approach in detecting serial correlation amongst the idiosyncratic errors implies the existence of unobserved effect. The point in using panel data in a good number of research applications is to allow for the unobserved effect, $\boldsymbol{\eta}_{i}$, to be randomly correlated with the set of independent variables, thereby necessitating the application of a fixed effect estimation procedure. The choice for employing either the fixed or random effect model estimation in the present study will be based on the outcome of the Hausman test result. The value of the Hausman test statistics will lead to either the acceptance or rejection of the null hypothesis. The null hypothesis will be rejected with a significant probability value of the Hausman test statistic and leads to the conclusion of the presence of fixed effects.

Following the works of Hulya Ulku (2007) and Yanrui Wu (2012), the study in addendum uses a dynamic panel technique in addressing potential problems of endogeneity in the data adopting the procedures by Arellano and Bover (1995) and Blundell and Bond (1998). This kind of dynamic panel framework is developed by the application of first difference transformation depicted by the following equation:

$y_{i, t}-y_{i, t-1}=(\alpha-1) y_{i, t-1}+\beta^{\prime} X_{i, t}+\eta_{i}+\varepsilon_{i, t}$

[Eqn 2] $y_{i, t}-y_{i, t-1}$ is real GDP per capita growth, $X_{i, t}$ denotes the set of independent variables including our measure of the NIS, $\eta_{i}$ denotes the unobserved country-specific effect and $\varepsilon_{i, t}$ denotes the error term. We continue by rewriting Equation 2 as:

$y_{i, t}=\alpha^{\prime} y_{i, t-1}+\beta^{\prime} X_{i, t}+\eta_{i}+\varepsilon_{i, t}$

[Eqn 3]

Transforming Equation 3 into first difference yields:

$y_{i, t}-y_{i, t-1}=\alpha^{\prime}\left[y_{i, t-1}-y_{i, t-2}\right]+\beta^{\prime}\left[X_{i, t}-X_{i, t-1}\right]+\left[\varepsilon_{i, t}-\varepsilon_{i, t-1}\right]$

[Eqn 4]

It is clearly shown in Equation 4 that the lagged difference in GDP per capita is correlated with the error term, which by implication of the potential endogeneity of the independent variable $X$ triggers the use of instrumental variables. In addressing this problem, the system difference estimator uses the lagged level of the independent variables as instruments in the assumption that the lagged levels of the independent variables are weakly exogenous and that the error term is serially uncorrelated. Following the works of Blundell and Bond (1998), we employ two tests of specification. We first use the Sargan test to verify for overidentification restriction to test the validity of the endogenous instruments. Second, we test for second-order serial correlation of the error term to verify whether the error term in the differenced equation model follows a process of first order moving average.

\section{Ethical consideration}

The authors have strived to honestly report methods, procedures, data and results. They have endeavoured to avoid bias in all aspects of the research where objectivity is expected or required. The authors have also honoured copyright and other forms of intellectual property rights, and they have given credits where due and properly acknowledged all contributions to the research.

\section{Estimation results}

In investigating the possibility of non-stationarity in the data set, it is crucial to first determine the existence of unit roots in the data series. In the present study, we have employed Levin, Lin and Chu (2002), Im, Pesaran and Shin (2003), ADF-Fisher (Dickey \& Fuller, 1979) and PP-Fisher (Phillips \& Perron 1988) panel unit root tests at first difference indicating that all the variables in the model are $\mathrm{I}(0)$. The results in Table 2 clearly show that the null hypothesis of a panel unit root (nonstationarity) at the levels of the series can be rejected.

As mentioned earlier in the methodology section, the study made use of the Hausman specification test in choosing between the fixed effect and random effect model in our estimation. From the results of the Hausman specification test presented in the lower section in Table 3, the individual unobserved country-specific effects are uncorrelated with the 
TABLE 2: Unit root test results.

\begin{tabular}{lcccc}
\hline Variable & LLC & IPS & ADF & PP \\
\hline Y & $-9.5067(0.0000)$ & $-2.6500(0.0040)$ & $72.656(0.0023)$ & $113.061(0.0000)$ \\
UE & $-6.2770(0.0000)$ & $-2.9902(0.0014)$ & $79.953(0.0004)$ & $190.729(0.0000)$ \\
RD & $-8.5962(0.0000)$ & $-2.6283(0.0043)$ & $69.835(0.0024)$ & $105.480(0.0000)$ \\
TM & $-8.3590(0.0000)$ & $-4.7910(0.0000)$ & $99.825(0.0000)$ & $183.932(0.0000)$ \\
PT & $-7.6154(0.0000)$ & $-3.3577(0.0004)$ & $87.550(0.0000)$ & $252.922(0.0000)$ \\
SP & $-3.8578(0.0001)$ & $-1.6960(0.0449)$ & $57.103(0.0141)$ & $71.3330(0.0004)$ \\
SJA & $-6.3425(0.0000)$ & $-2.5700(0.0051)$ & $66.341(0.0097)$ & $144.240(0.0000)$ \\
EF & $-9.0523(0.0000)$ & $-2.8836(0.0020)$ & $81.988(0.0009)$ & $166.799(0.0000)$ \\
\hline
\end{tabular}

Note: probabilities for Fisher tests are calculated using asymptotic Chi-square distribution. All other tests assume asymptotic normality. Values in parentheses are the probability values for the tests.

Y, GDP per capita growth; UE, university enrolment for science and engineering students; RD, government research and development expenditure; TM, value of high-tech export; PT, tota number of patents; SP, scientific personnel; SJA, scientific and technical journal articles; EF, economic freedom

explanatory variables, suggesting that the fixed effect model is preferable to the random effect model for the regression estimates. We therefore consider only the fixed effect estimate in the level analysis. However, we also estimated the random effect model for sensitivity purpose in order to make a meaningful comparison. We also used the Arellano-Bond approach of the GMM as it accounts for endogeneity problem ${ }^{3}$ in estimating the parameters of the dynamic panel model. The Sargan test result shows validity in the instruments employed in correcting potential endogeneity in the data set used in estimating the dynamic panel model. Finally, the residual of the dynamic panel model does not suffer from any serious problem of second-order serial correlation. Since the relative effect of the explanatory variables on GDP per capita growth is accounted for from the dynamic panel model, interpretation of the relative effect will be based on the results from the dynamic panel model.

In the regression model shown in Table 3, the adjusted $\mathrm{R}$-squared value for the fixed effect model which has been selected against the random effect model for this analysis is 0.9268 , which explains $92 \%$ variation in the growth rate of GDP in Brazil, Russia, India, China and South Africa. The value of the F-statistics is 421.597, and its associated probability value is 0.000 which shows that the results are jointly statistically significant and the null hypothesis of the explanatory variables having no effect on growth in the five countries is rejected.

Furthermore, university enrolment rate of science and engineering students, government expenditure on R\&D, high-tech market, patent and scientific and technical journal articles are statistically significant in the fixed effect model. The coefficients of these variables as a measure of the NIS are positive and statistically significant at the $1 \%$ and $5 \%$ levels of significance which implies that the NIS as a whole has a positive effect on economic growth in BRICS economies and in consequence spurs their economic growth. With regard to the relative effect which is explained by the dynamic panel model, the coefficients of university enrolment rate of science and engineering students, government expenditure on R\&D, high-tech market and scientific personnel are also positive and statistically significant in explaining the growth rate of GDP in BRICS except for scientific and technical journal articles which show a negative impact in this model. The results as a whole have shown a positive impact of the NIS on the economic growth of BRICS. For instance, the coefficient of the variable representing university enrolment of science and engineering students (UE) is positive and statistically significant at the $1 \%$ level of significance for both the fixed effect and dynamic panel model. Therefore, university enrolment of science and engineering students has a significant positive effect on economic growth which means, by implication from the dynamic panel model, enhancing university enrolment of science and engineering students by $10 \%$ will spur economic growth by approximately $0.11 \%$.

Similarly, the coefficient of the variable representing government expenditure on $R \& D$ is positive and highly statistically significant in both the fixed effect and dynamic panel model which means, by implication from the dynamic panel model, increasing government R\&D expenditure by $10 \%$ will induce economic growth by approximately. $0.13 \%$. This finding is in conformity with theories and in line with findings by Hulya Ulku (2007) and Yanrui Wu (2012) that there is positive relationship between $R \& D$ expenditure and economic growth and that increase in $R \& D$ expenditure will eventually induce economic growth.

The coefficient of high-tech market is also positive and statistically significant at the $1 \%$ level of significance for both the fixed effect and dynamic panel model estimates. From the relative effect by the dynamic panel model, enhancing hightech market development by $10 \%$ will promote economic growth by approximately $0.15 \%$.

Unlike the panel dynamic model, the coefficient of the variable representing patent is positive and statistically significant at the $1 \%$ level of significance in the fixed effect model. This implies that an increase in the number of patents by $10 \%$ will induce economic growth by approximately $0.02 \%$.

Also, the coefficient of scientific personnel is positive and significant only in the dynamic panel model. This implies that augmenting the number of scientific personnel by $10 \%$ promotes economic growth by a margin of $0.09 \%$. Finally, the relationship between scientific and technical journal articles and economic growth is positive and statistically significant in the fixed effect model estimate. This implies that encouraging scientific journal publication is as well very important in boosting economic growth in BRICS economies. However, economic freedom was not found to be statistically significant for the study, which means that economic freedom is not contributing significantly towards growth amongst BRICS member countries. This can be attributed to the fact that, unlike for South Africa, BRICS countries are below the average economic freedom score of countries as reported by the global economy in 2013. It can also be the case that most 
TABLE 3: Panel estimation results.

\begin{tabular}{llll}
\hline Variables & Fixed effect model & Random effect model & GMM dynamic panel model (first difference) \\
\hline $\mathrm{c}$ & $0.7013(15.629)^{* * *}$ & $0.7007(16.059)^{* * *}$ & $\mathrm{n} / \mathrm{a}$ \\
$\mathrm{Y}_{-1}$ & $\mathrm{n} / \mathrm{a}$ & $\mathrm{n} / \mathrm{a}$ & $0.0461(1.3429)$ \\
UE & $0.3007(8.5396)^{* * *}$ & $0.3000(8.3576)^{* * *}$ & $0.1136(4.4530)^{* * *}$ \\
RD & $0.2070(11.085)^{* * *}$ & $0.2043(11.145)^{* * *}$ & $0.1325(9.3561)^{* * *}$ \\
TM & $0.3885(10.810)^{* * *}$ & $0.3896(11.096)^{* * *}$ & $0.1519(7.4634)^{* * *}$ \\
PT & $0.0190(6.7452)^{* * *}$ & $0.0190(6.7067)^{* *}$ & $0.02835(1.1341)$ \\
SP & $0.0162(0.2598)$ & $0.0187(0.3091)$ & $0.0925(2.2441)^{* *}$ \\
SJA & $0.0176(2.3756)^{* * *}$ & $0.0159(2.1302)^{* *}$ & $0.0103(2.0751)^{*}$ \\
EF & $-0.0569(-1.3844)$ & $-0.0435(-1.0560)$ & $0.07679(0.1967)$ \\
Observations & 280 & 280 & 280 \\
$R^{2}$ & 0.9268 & 0.9283 & $\mathrm{n} / \mathrm{a}$ \\
F-Statistics & $421.597(0.0000)^{* * *}$ & $406.086(0.0000)^{* * *}$ & $\mathrm{n} / \mathrm{a}$ \\
$\chi 2-$ Hausman test & $\mathrm{n} / \mathrm{a}$ & $18.7737(0.0089)^{* * *}$ & $\mathrm{n}$ \\
Second-order serial correlation test & $\mathrm{n} / \mathrm{a}$ & $\mathrm{n} / \mathrm{a}$ & $\mathrm{H}$ \\
Sargan Test & $\mathrm{n} / \mathrm{a}$ & $\mathrm{n} / \mathrm{a}$ & \\
\hline
\end{tabular}

Note: A significant $\chi 2$ (Hausman test) value implies that we reject the random effect model (against the fixed effect model). The fixed and random effects models are estimated using panel Generalised Least Squares with cross-section weights. Values in parenthesis are $t$ values.

Y, GDP per capita growth; UE, university enrolment for science and engineering students; RD, government research and development expenditure; TM, value of high-tech export; PT, total number of patents; SP, scientific personnel; SJA, scientific and technical journal articles; EF, economic freedom.

$* * *, * *$ and $*$, significance at $1 \%, 5 \%$ and $10 \%$ levels, respectively; $n / a$, not applicable.

of the BRICS countries, especially China, have a strong government with a lower level of degree of freedom, but the high-tech export is high and the NIS is efficient. It means that authoritative government could make the NIS more effective than countries who have free market economy.

\section{Robustness check for panel regression estimates}

In order to ascertain the relative stability of our regression estimates, we carry out robustness checks by introducing new explanatory variable openness. Imports plus exports scaled up by GDP are denoted as (Open) in the base regressions. The exercise entails comparing the new parameters obtained by introducing a new explanatory variable in the new model to the original estimates of the base regression. The idea is to check if the parameter estimates from the new regression do not change much in terms of the signs and level of significance from those of the base regression; we therefore consider the estimates from the base regression as robust. The results of the robustness checks with the new instrument (Open) are reported in Table 4. The results from the robustness checks reveal that the coefficients of all the variables in our base regressions fail to vary significantly from those of the new estimates, therefore implying that the parameter estimates from our panel regressions are robust. This confirms the appropriateness of the estimations techniques and that the model has been well specified. The R-squared values (coefficient of determination) reasonably explained the proportion by which the regression model is best fitted.

\section{Conclusion}

This study, which in essence aims at unearthing the relationship between the NIS and economic growth in BRICS, employs an endogenous growth framework to better capture the impact of the NIS on growth. Consistent and reliable panel data spanning from 2000 to 2013 for the selected emerging economies were sourced from the International Financial Statistics, World Intellectual Property Organization and the World Bank database. The panel data set was then interpolated to increase the sample size so as to be able to draw conclusion out of it. A panel estimation approach was employed using Hausman specification test in choosing between the fixed effect and the random effect model in our estimation. From the results of the Hausman specification test, the individual, unobserved country-specific effects were found to be uncorrelated with the explanatory variables, which suggested the preference of the fixed effect over the random effect model. The Sargan test result for over-identification restriction also shows validity in the instruments employed in correcting potential endogeneity in the data set used in estimating the dynamic panel model. Findings from this study reveal that developing a NIS in BRICS economies is exceptionally crucial in advancing a constructive approach for promoting sustainable growth in emerging economies. Results from this study as a whole reveal that increasing the role played by universities, governments and businesses will eventually lead to an increase in economic growth. An important policy implication emerging from this study is that extra efforts are needed by emerging economies to promote the development of a NIS so as to explore the potential growth-inducing effects of a well-functioning NIS. Consequently, findings from this study have offered some persuading indicators for BRICS economies to explore the development of a NIS as a potential opportunity to speed up their economic growth.

\section{Acknowledgements}

The authors acknowledge Professor Wei Long, Dean, School of Economics, Wuhan University of Technology, for his brilliant research assistance, and all anonymous referees for their valuable comments and suggestions. This research was supported by the China National Social Science Fund (No. 11AzD081) and the China National Natural Science Fund (No. 71203172). 
TABLE 4: Robustness check of the panel data estimate.

\begin{tabular}{|c|c|c|c|c|c|c|}
\hline \multirow[t]{3}{*}{ Variable } & \multicolumn{6}{|c|}{ Estimators } \\
\hline & \multicolumn{2}{|c|}{ Fixed effect model } & \multicolumn{2}{|c|}{ Random effect model } & \multicolumn{2}{|c|}{ GMM dynamic panel model (first difference) } \\
\hline & Base model & New model & Base model & New model & Base model & New model \\
\hline c & $\begin{array}{c}0.7013 \\
(15.629)^{* * *}\end{array}$ & $\begin{array}{c}0.8263 \\
(16.359)^{* * *}\end{array}$ & $\begin{array}{c}0.7007 \\
(16.059)^{* * *}\end{array}$ & $\begin{array}{c}0.8034 \\
(16.783)^{* * *}\end{array}$ & $n / a$ & $\mathrm{n} / \mathrm{a}$ \\
\hline $\mathrm{y}_{-1}$ & $\mathrm{n} / \mathrm{a}$ & $\mathrm{n} / \mathrm{a}$ & $\mathrm{n} / \mathrm{a}$ & $\mathrm{n} / \mathrm{a}$ & $\begin{array}{c}0.0461 \\
(1.3429)\end{array}$ & $\begin{array}{c}0.0525 \\
(1.0345)\end{array}$ \\
\hline UE & $\begin{array}{c}0.3007 \\
(8.5396)^{* * *}\end{array}$ & $\begin{array}{c}0.3102 \\
(9.1301)^{* * *}\end{array}$ & $\begin{array}{c}0.3000 \\
(8.3576)^{* * *}\end{array}$ & $\begin{array}{c}0.3063 \\
(8.7360)^{* * *}\end{array}$ & $\begin{array}{c}0.1136 \\
(4.4530)^{* * *}\end{array}$ & $\begin{array}{c}0.1311 \\
(4.7821)^{* * *}\end{array}$ \\
\hline RD & $\begin{array}{c}0.2070 \\
(11.085)^{* * *}\end{array}$ & $\begin{array}{c}0.2099 \\
(12.005)^{* * *}\end{array}$ & $\begin{array}{c}0.2043 \\
(11.145)^{* * *}\end{array}$ & $\begin{array}{c}0.3032 \\
(12.528)^{* * *}\end{array}$ & $\begin{array}{c}0.1325 \\
(9.3561)^{* * *}\end{array}$ & $\begin{array}{c}0.1396 \\
(8.7290)^{* * *}\end{array}$ \\
\hline TM & $\begin{array}{c}0.3885 \\
(10.810)^{* * *}\end{array}$ & $\begin{array}{c}0.3737 \\
(10.728)^{* * *}\end{array}$ & $\begin{array}{c}0.3896 \\
(11.096)^{* * *}\end{array}$ & $\begin{array}{c}0.3395 \\
(11.625)^{* * *}\end{array}$ & $\begin{array}{c}0.1519 \\
(7.4634)^{* * *}\end{array}$ & $\begin{array}{c}0.1598 \\
(9.2543)^{* * *}\end{array}$ \\
\hline PT & $\begin{array}{c}0.0190 \\
(6.7452)^{* * *}\end{array}$ & $\begin{array}{c}0.0207 \\
(7.2325)^{* * *}\end{array}$ & $\begin{array}{c}0.0190 \\
(6.7067) * *\end{array}$ & $\begin{array}{c}0.0204 \\
(8.425)^{* *}\end{array}$ & $\begin{array}{l}0.02835 \\
(1.1341)\end{array}$ & $\begin{array}{l}0.02165 \\
(1.4003)\end{array}$ \\
\hline SP & $\begin{array}{c}0.0162 \\
(0.2598)\end{array}$ & $\begin{array}{c}0.0133 \\
(0.2134)\end{array}$ & $\begin{array}{c}0.0187 \\
(0.3091)\end{array}$ & $\begin{array}{c}0.0216 \\
(0.2993)\end{array}$ & $\begin{array}{c}0.0925 \\
(2.2441)^{* *}\end{array}$ & $\begin{array}{c}0.1010 \\
(2.7632)^{* *}\end{array}$ \\
\hline SJA & $\begin{array}{c}0.0176 \\
(2.3756)^{* * *}\end{array}$ & $\begin{array}{c}0.0183 \\
(3.2672)^{* * *}\end{array}$ & $\begin{array}{c}0.0159 \\
(2.1302)^{* *}\end{array}$ & $\begin{array}{c}0.0143 \\
(2.6549)^{* *}\end{array}$ & $\begin{array}{c}0.0103 \\
(2.0751)^{*}\end{array}$ & $\begin{array}{c}0.0196 \\
(3.6220)^{* *}\end{array}$ \\
\hline EF & $\begin{array}{c}-0.0569 \\
(-1.3844)\end{array}$ & $\begin{array}{c}-0.0282 \\
(-1.0062)\end{array}$ & $\begin{array}{c}-0.0435 \\
(-1.0560)\end{array}$ & $\begin{array}{l}-0.0504 \\
(-0.936)\end{array}$ & $\begin{array}{l}0.07679 \\
(0.1967)\end{array}$ & $\begin{array}{c}0.0796 \\
(0.0954)\end{array}$ \\
\hline Open (new instrument) & $\mathrm{n} / \mathrm{a}$ & $\begin{array}{c}0.0451 \\
(6.9346)^{* * *}\end{array}$ & $\mathrm{n} / \mathrm{a}$ & $\begin{array}{c}0.0426 \\
(7.3690)^{* * *}\end{array}$ & $\mathrm{n} / \mathrm{a}$ & $\begin{array}{c}0.0276 \\
(6.5621)^{* * *}\end{array}$ \\
\hline Observations & 280 & 280 & 280 & 280 & 280 & 280 \\
\hline$R^{2}$ & 0.9268 & 0.9152 & 0.9283 & 0.9033 & $\mathrm{n} / \mathrm{a}$ & $\mathrm{n} / \mathrm{a}$ \\
\hline F-statistics & $\begin{array}{c}421.597 \\
(0.0000)^{* * *}\end{array}$ & $\begin{array}{c}321.346 \\
(0.000)^{* * *}\end{array}$ & $\begin{array}{c}406.086 \\
(0.0000)^{* * *}\end{array}$ & $\begin{array}{c}292.463 \\
(0.000) * * *\end{array}$ & $\mathrm{n} / \mathrm{a}$ & $\mathrm{n} / \mathrm{a}$ \\
\hline$\chi 2-$ Hausman test & $\mathrm{n} / \mathrm{a}$ & $\mathrm{n} / \mathrm{a}$ & $\begin{array}{c}18.7737 \\
(0.0089)^{* * *}\end{array}$ & $\begin{array}{c}15.4872 \\
(0.0031)^{* * *}\end{array}$ & $\mathrm{n} / \mathrm{a}$ & $\mathrm{n} / \mathrm{a}$ \\
\hline $\operatorname{AR}(2)$ & $\mathrm{n} / \mathrm{a}$ & $\mathrm{n} / \mathrm{a}$ & $\mathrm{n} / \mathrm{a}$ & $\mathrm{n} / \mathrm{a}$ & $\begin{array}{c}Z=-5.4627 \\
(0.0008)\end{array}$ & $\begin{array}{c}Z=-5.0521 \\
(0.0004)\end{array}$ \\
\hline Sargan test & $\mathrm{n} / \mathrm{a}$ & $n / a$ & $\mathrm{n} / \mathrm{a}$ & $\mathrm{n} / \mathrm{a}$ & $\begin{array}{c}\chi^{2}=29.356 \\
(0.6382)\end{array}$ & $\begin{array}{c}\chi^{2}=33.278 \\
(0.4762)\end{array}$ \\
\hline
\end{tabular}

Y, GDP per capita growth; UE, university enrolment for science and engineering students; RD, government research and development expenditure; TM, value of high-tech export; PT, total number of patents; SP, scientific personnel; SJA, scientific and technical journal articles; EF, economic freedom.

Note: A significant $\chi 2$ (Hausman test) value implies that we reject the random effect model (against the fixed effect model). The fixed and random effects models are estimated using panel Generalised Least Squares with cross-section weights. Values in parenthesis are $t$ values.

$* * *, * *$ and $*$, significance at $1 \%, 5 \%$ and $10 \%$ levels, respectively; $n / a$, not applicable.

\section{Competing interests}

There is no competing interest.

\section{Authors' contributions}

Mr. Brima Sesay is the first author and has focused mainly on the structure of the article and data analysis and interpretations. Professor Zhao Yulin is the second author and has focused mainly on the literature review, identified gaps in the literature and provided guidance on the selection of the variables. Associate professor Fang Wang assisted in reviewing the manuscript and made adjustments on it.

\section{References}

Aghion, P. \& Howitt, P., 1998, Endogenous growth theory, The MIT Press, Cambridge, MA.

Arellano, M. \& Bond, S., 1991, 'Some tests of specification for panel data: Monte Carlo evidence and an application to employment equations', The Review of Economic Studies 58(2), 277-297. https://doi.org/10.2307/2297968

Arellano, M. \& Bover, O., 1995, 'Another look at the instrumental-variable estimation of error-components models', Journal of Econometrics 68(1), 29-51. https://doi. org/10.1016/0304-4076(94)01642-D

Blundell, R. \& Bond, S., 1998, 'Initial conditions and moment restrictions in dynamic panel data models', Journal of Econometrics 87(1), 115-143. https://doi.org/ $10.1016 / \mathrm{S} 03044076(98) 00009-8$

Breschi, S. \& Malerba, F., 1997, 'Sectoral systems of innovation: Technological regimes, Schumpeterian dynamics and spatial boundaries', in C. Edquist (ed.), Systems of innovation, pp. 130-156, Frances Pinter, London.

Carlsson, B. \& Stankiewicz, R., 1995, 'On the nature, function and composition of technological systems', in B. Carlsson (ed.), Technological systems and economic performance: The case of factory automation, pp. 21-56, Kluwer Academic Publishers, Dordrecht.
Dickey, D.A. \& Fuller, W.A., 1979, 'Distribution of the estimators for autoregressive time series with a unit root', Journal of the American Statistical Association 74 427-431.

Dutta, A. \& Sharmat, S., 2008, Intellectual property rights and innovation in developing countries: Evidence from India, World Bank Group, viewed 03 Jan. 2016, from https://www.enterprisesurveys.org/ /media/GIAWB/EnterpriseSurveys/ Documents/ResearchPapers/Intellectual_Property_Rights_India.pdf

Falvey, R., Foster, N. \& Greenaway, D., 2006, 'Intellectual property rights and economic growth', Review of Development Economics 10(4), 700-719. https://doi.org/ 10.1111/j.1467-9361.2006.00343.x

Frantzen, D., 2000, 'R\&D, human capital and international technology spillovers: A cross country analysis', Scandinavian Journal of Economics 102(1), 57-75. https:// doi.org/10.1111/1467-9442.00184

Freeman, C., 1982, 'Technological infrastructure and international competitiveness', Industrial and Corporate Change 13(3), 541-569. https://doi.org/10.1093/icc/ Industrial
dth022

Ginarte, J. \& Park, W., 1997, 'Determinants of patent rights: A cross national study', Research Policy 26(30), 283-301. https://doi.org/10.1016/S0048-7333(97)00022-X

Gould, D. \& Gruben, W., 1996, 'The role of intellectual property rights in economic growth', Journal of Development Economics 48, 323-350. https://doi.org/10.1016/ 0304-3878(95)00039-9

Griffith, R., Redding, S. \& Van Reenen, J., 2002, Mapping the two faces of R\&D: Productivity growth in a panel of OECD countries, Working Paper, 02/00, The Institute for Fiscal Studies, London, United Kingdom.

Griliches, Z. \& Lichtenberg, F., 1984, 'Interindustry technology flows and productivity growth: A reexamination', Review of Economics and Statistics 66, 324-329. https://doi.org/10.2307/1925836

Hall, B.H. \& Ziedonis, R.H., 2001, 'The patent paradox revisited: An empirical study of patenting in the U.S. semiconductor industry, 1979-1995', RAND Journal of Economics 32(1), 101-128. https://doi.org/10.2307/2696400

Im, K.S., Pesaran, M.H. \& Shin, Y., 2003, 'Testing for unit roots in heterogeneous panels', Journal of Econometrics 115, 53-74. https://doi.org/10.1016/S0304 4076(03)00092-7

Intarakumnerd, P., Chairatana, P. \& Tangchitpiboon, T., 2002, 'National innovation system in less successful developing countries: The case of Thailand', Research Policy 31, 1445-1457. https://doi.org/10.1016/S0048-7333(02)00074-4

Jacobsson, S. \& Johnson, A., 2000, 'The diffusion of renewable energy technology: An analytical framework and key issues for research', Energy Policy, 28(9), 625-640. https://doi.org/10.1016/S0301-4215(00)00041-0 
Jones, C.I., 1995, 'Time series test of endogenous growth models', Quarterly Journal of Economics 110(2), 495-525. https://doi.org/10.2307/2118448

Levin, A., Lin, C.F. \& Chu, C., 2002, 'Unit root tests in panel data: Asymptotic and finite sample properties', Journal of Econometrics 108, 1-24. https://doi.org/10.1016/ S0304-4076(01)00098-7

McCalman, P., 2005, 'Who enjoys "TRIPs" abroad? An empirical analysis of intellectual property rights in the Uruguay round', Canadian Journal of Economics 38(2), 574-603. https://doi.org/10.1111/j.0008-4085.2005.00293.x

Phillips, P. \& Perron, P., 1988, 'Testing for a unit root in time series regression' Biometrika 75, 335-346. https://doi.org/10.1093/biomet/75.2.335

Porter, M., 1990, The competitive advantage of nations, The Free Press, New York.

Romer, P.M., 1986, 'Increasing returns and long run growth', Journal of Political Economy 94, 1002-1037. https://doi.org/10.1086/261420

Romer, P.M., 1990, 'Endogenous technical change', Journal of Political Economy 98(5), 71-102. https://doi.org/10.1086/261725

Scherer, F.M., 1982, 'Inter-industry technology flows and productivity growth', Review of Economics and Statistics 64, 627-634. https://doi.org/10.2307/1923947

Schneider, P.H., 2005, 'International trade, economic growth and intellectual property rights: A panel data study of developed and developing countries', Journal of rights: A panel data study of developed and developing countries', Journal of
Development Economics 78, 529-547. https://doi.org/10.1016/j.jdeveco.2004.09.001

Schumpeter, J.A., 1969, The theory of economic development, Oxford University Press, Oxford.
Smith, P.J., 2001, 'How do foreign patent rights affect U.S exports, affiliate sales and licenses?', Journal of International Economics 55, 411-439. https://doi.org/ 10.1016/S0022-1996(01)00086-1

The Global Economy, 2013, viewed 15 Jan. 2016, from http://www.theglobaleconomy $\mathrm{com} /$

The World Bank, 2014, World Development Indicators, International Bank for Reconstruction and Development/The World Bank, Washington DC.

Ulku, H., 2007, 'R\&D, innovation, and economic growth: Evidence from four manufacturing sectors in OECD countries', Oxford Economic Papers 59, 513-535. https://doi.org/10.1093/oep/gpl022

Valetina, G., Sergey, M. \& Sergey, M., 2013, 'Nano-economics in a national system of innovation', Procedia Economics and Finance 5, 288-295. https://doi.org/10.1016/ S2212-5671(13)00035-X

World Development Indicator, 2014, CD-ROM, viewed 04 Mar. 2015, from http:// www.worldbank.org

Wu, Y., 2012, Innovation and economic growth in China, The University of Western Australia, Discussion Paper 10.10, viewed 03 Jan. 2016, from https:// timedotcom.files.wordpress.com/2015/04/10-10 innovation_and_economic growth_in_china.pdf

Zachariadis, M., 2003, 'R\&D, innovation, and technological progress: A test of the Schumpeterian framework without scale effects', Canadian Journal of Economics 36(3), 566-686. https://doi.org/10.1111/1540-5982.t01-2-00003 
Page 12 of 12

Original Research

Appendix 1

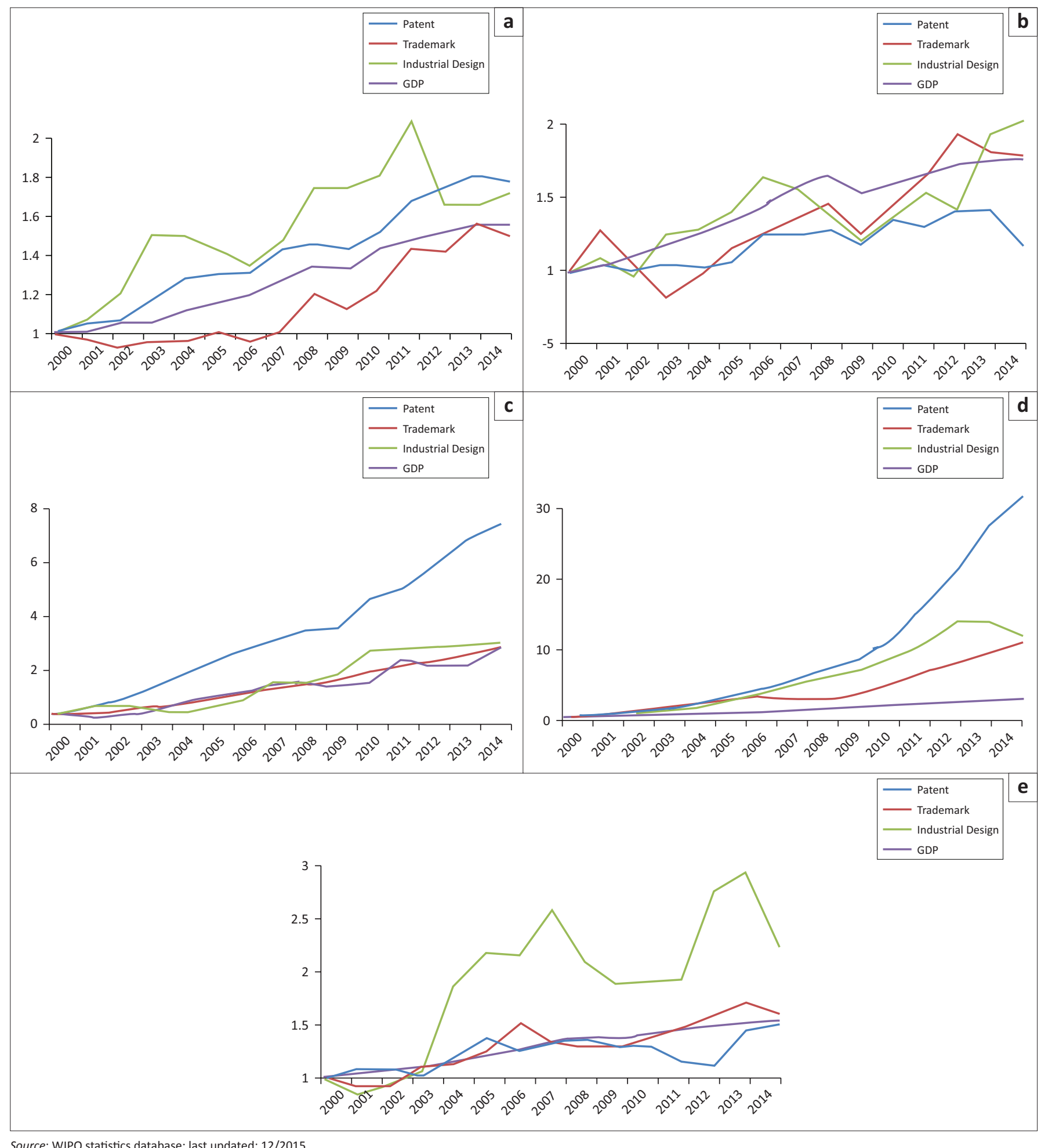

FIGURE 1-A1: Intellectual property filings and economic growth for (a) Brazil, (b) Russia, (c) India, (d) China and (e) South Africa

http://www.sajems.org

Open Access 